\title{
CADAVER STUDY OF THE EXTENSION OF THE LOBES OF THE THYROID GLAND
}

\author{
NURUNNABI ASM ${ }^{1}$, ARA S $^{2}$, AHMED R $^{1}$, KISHWARA $^{3}$, MAHBUB S $^{4}$, FARUQUE ABMO $^{5}$
}

\begin{abstract}
:
Context: The present study was designed to see the extension i.e. the superior and the inferior limits of the right and the left lobes of the thyroid gland of Bangladeshi people and compare with the previous studies.

Study design: Descriptive type of study.

Place and period of the study: Department of Anatomy, Dhaka Medical College, Dhaka from January to December 2008.

Materials: The present study was performed on 60 post mortem human thyroid gland (39 of male and 21 of female) of unclaimed dead bodies which were in the morgue under examination in the Department of Forensic Medicine, Dhaka Medical College, Dhaka.

Methods: The samples were collected from the dead bodies by 'block dissection' and upper and lower limits of the lobes of the thyroid gland were observed in situ and recorded.

Results: The superior limit of the right and left lobes of the thyroid glands reached above the midpoint of the lamina of the thyroid cartilage in $16.67 \%$ and $8.33 \%$ cases and was found at the level of that midpoint in $41.67 \%$ and $43.33 \%$ of cases respectively. $41.67 \%$ on the right and $48.33 \%$ on the left could not reach that midpoint of the thyroid cartilage. The inferior limit of the right and left lobes of the thyroid gland reached up to the $5^{\text {th }}$ tracheal ring in $63.33 \%$ and $60 \%$ cases respectively and inferiorly up to the $6^{\text {th }}$ tracheal ring in $36.67 \%$ and $40 \%$ cases respectively.
\end{abstract}

Key words: Thyroid gland, extension of lobes, superior and inferior limit.

J Dhaka Med Coll. 2010; 19(1) : 47-50.

\section{Introduction:}

The thyroid gland is an important endocrine gland in human body, which is situated anteriorly in the lower part of the neck extending from the level of the $5^{\text {th }}$ cervical to the $1^{\text {st }}$ thoracic vertebrae, consists of two symmetrical lobes connected by an isthmus ${ }^{1}$. Thyroid disorder is a common health problem among large number of endocrinopathies. About $5 \%$ of the world population is affected from various thyroid diseases. Most of the diseases affecting the thyroid gland e.g. goitre, thyrotoxicosis, adenoma, carcinoma etc. are usually associated with enlargement of the gland and require medical and surgical intervention ${ }^{2}$. There are many variations in the shape, size and relative level of the thyroid gland ${ }^{3}$. Therefore, knowledge of the variation in morphological and topographical anatomy is very important in the evaluation and management of the thyroid disorders in clinical practice ${ }^{4}$. Moreover, it has been observed by various researchers that the dimensions of different organs in Bangladeshi population have got variations from those of the western population ${ }^{5}$. Variations in lobar extension i.e. superior and inferior limits, is of great importance to the pathologists, sonologists and specially the surgeons in diagnoses and management of the thyroid diseases. The present study is an approach to objective to increase the information pool and help the clinicians in their practice.

\section{Materials and Methods: \\ Materials of the study:}

A descriptive type of study was done in the Department of Anatomy, Dhaka Medical

1. Lecturer, Department of Anatomy, Dhaka Medical College, Dhaka.

2. Professor and Head, Department of Anatomy, Dhaka Medical College, Dhaka.

3. Assistant Professor, Department of Anatomy, Dhaka Medical College, Dhaka.

4. Assistant Professor, Department of Anatomy, Tairunnessa Memorial Medical College, Gazipur.

5. Associate Professor, Department of Anatomy, Tairunnessa Memorial Medical College, Gazipur.

Correspondence: Dr. Abu Sadat Mohammad Nurunnabi 
College, Dhaka from January to December 2008 , based on collection of 60 human thyroid glands from the unclaimed dead bodies that were under examination in the Department of Forensic Medicine, Dhaka Medical College, Dhaka from February to October 2008. The samples were collected within 24-36 hours of death without any sign of putrefaction and from medicolegal cases excluding hanging, poisoning, any cutting or crushing injury to the thyroid gland and known case of thyroid disease.

\section{Ethical clearance:}

This research work was approved by the Ethical Review Committee of Dhaka Medical College, Dhaka.

\section{Methods of the study:}

Grouping of the sample:

After isolation, the samples were divided into three age-groups i.e. Group A (10-20 years), Group B (21-50 years) \& Group C (>50 years) (Table:I) for convenience of the study, according to Brown, Al-Moussa and Beck (1986) ${ }^{6}$.

Procedure of the study:

The anterior aspect of the specimen consisting of pharynx, part of oesophagus, larynx, trachea, thyroid and parathyroid glands, major vessels of the neck was dissected. During dissection of the specimen, observation notes were taken about the upper and lower limits of the lobes of the thyroid gland. The extensions of the thyroid gland i.e. superior and inferior limits were observed very carefully. The superior extension of each lobe of the thyroid gland was marked by a pin-marking on underlying thyroid cartilage and after removal of the whole of the thyroid gland, the distance between the points of junction of the cornua with the lamina of the thyroid cartilage above and below was measured with the help of a thread and then the thread was imposed on a measuring tape, on each side. Then the midpoint of that distance was determined. After that, the relative position of the pin-mark with that midpoint was noted on both sides. Then, at the inferior pole of lobes pin-mark was given and just after removal of whole of the thyroid gland, the inferior limit was noted by identifying the tracheal ring on which the pin-mark was given.

\section{Exclusion criteria:}

1. Death due to hanging or poisoning,

2. Any cutting or crushing injury to the thyroid gland,

3. Thyroid gland found in one side,

4. Abnormal difference in size between the lobes,

5. Any known case of thyroid disease.

\section{Results:}

In the present study, the superior limit of the right and left lobes of the thyroid glands reached above the midpoint of the line joining the junctions of superior and inferior cornua with the lamina of the thyroid cartilage in $16.67 \%$ and $8.33 \%$ of cases respectively. In $41.67 \%$ of cases of the right lobe and $43.33 \%$ of cases of the left lobe, the superior limits were at the level of that midpoint. In $41.67 \%$ on the right and $48.33 \%$ on the left could not reach that midpoint of the thyroid cartilage respectively.

The inferior limit of the right and left lobes of the thyroid gland reached up to the $5^{\text {th }}$ tracheal ring in $63.33 \%$ and $60 \%$ cases respectively and reached up to the $6^{\text {th }}$ tracheal ring in $36.67 \%$ and $40 \%$ cases respectively.

\section{Table-I}

Grouping of the sample of the present study $(n=60)$

\begin{tabular}{lccc}
\hline Group & $\begin{array}{c}\text { Age limit } \\
\text { (in years) }\end{array}$ & \multicolumn{2}{c}{ Number of samples } \\
\cline { 3 - 4 } & $10-20$ & Male & Female \\
\hline A & $21-50$ & 24 & 05 \\
B & $>50$ & 07 & 10 \\
C & & 06 \\
\hline
\end{tabular}

The extensions of the superior limit of the lobes of the thyroid gland are shown in Table: II, Fig. 1 (a) and the inferior limits of the lobes are shown in Table: II, Fig. 1(b), according to different age group. 
Table-II

Extension of the lobes of the thyroid gland

\begin{tabular}{|c|c|c|c|c|c|c|c|c|c|c|}
\hline \multirow[t]{3}{*}{ Group/ Sex (n) } & \multicolumn{6}{|c|}{$\begin{array}{l}\text { Superior limit in relation to the midpoint } \\
\text { of the lamina of the thyroid cartilage }\end{array}$} & \multicolumn{4}{|c|}{$\begin{array}{l}\text { Inferior limit in relation } \\
\text { to the tracheal ring }\end{array}$} \\
\hline & \multicolumn{3}{|c|}{ Right lobe } & \multicolumn{3}{|c|}{ Left lobe } & \multicolumn{2}{|c|}{ Right lobe } & \multicolumn{2}{|c|}{ Left lobe } \\
\hline & $\overline{\mathrm{At}}$ & Below & Above & At & Below & Above & $5^{\text {th }}$ & 6 th & 5 th & 6 th \\
\hline A & 3 & 2 & 3 & 4 & 1 & 3 & 3 & 5 & 5 & 3 \\
\hline Male (8) & $5 \%$ & $3.33 \%$ & $5 \%$ & $6.67 \%$ & $1.67 \%$ & $5 \%$ & $5 \%$ & $8.33 \%$ & $8.33 \%$ & $5 \%$ \\
\hline Female (5) & $\begin{array}{c}4 \\
6.67 \%\end{array}$ & 0 & $\begin{array}{c}1 \\
1.67 \%\end{array}$ & $\begin{array}{l}3 \\
5 \%\end{array}$ & 0 & $\begin{array}{c}2 \\
3.33 \%\end{array}$ & $\begin{array}{l}3 \\
5 \%\end{array}$ & $\begin{array}{c}2 \\
3.33 \%\end{array}$ & $\begin{array}{c}4 \\
6.67 \%\end{array}$ & $\begin{array}{c}1 \\
1.67 \%\end{array}$ \\
\hline B & 11 & 9 & 4 & 10 & 11 & 3 & 16 & 8 & 12 & 12 \\
\hline Male (24) & $18.33 \%$ & $15 \%$ & $6.67 \%$ & $16.67 \%$ & $18.33 \%$ & $5 \%$ & $26.67 \%$ & $13.33 \%$ & $20 \%$ & $20 \%$ \\
\hline Female (10) & $\begin{array}{c}7 \\
11.67 \%\end{array}$ & $\begin{array}{c}2 \\
3.33 \%\end{array}$ & $\begin{array}{c}1 \\
1.67 \%\end{array}$ & $\begin{array}{c}6 \\
10 \%\end{array}$ & $\begin{array}{c}2 \\
3.33 \%\end{array}$ & $\begin{array}{c}2 \\
3.33 \%\end{array}$ & $\begin{array}{c}7 \\
11.67 \%\end{array}$ & $\begin{array}{l}3 \\
5 \%\end{array}$ & $\begin{array}{c}6 \\
10 \%\end{array}$ & $\begin{array}{c}4 \\
6.67 \%\end{array}$ \\
\hline $\mathrm{C}$ & 2 & 3 & 2 & 4 & 2 & 1 & 5 & 2 & 4 & 3 \\
\hline Male (7) & $3.33 \%$ & $5 \%$ & $3.33 \%$ & $6.67 \%$ & $3.33 \%$ & $1.67 \%$ & $8.38 \%$ & $3.33 \%$ & $6.67 \%$ & $5 \%$ \\
\hline Female (6) & $\begin{array}{c}3 \\
5 \%\end{array}$ & $\begin{array}{c}1 \\
1.67 \%\end{array}$ & $\begin{array}{c}2 \\
3.33 \%\end{array}$ & $\begin{array}{l}3 \\
5 \%\end{array}$ & $\begin{array}{c}1 \\
1.67 \%\end{array}$ & $\begin{array}{c}2 \\
3.33 \%\end{array}$ & $\begin{array}{c}4 \\
6.67 \%\end{array}$ & $\begin{array}{c}2 \\
3.33 \%\end{array}$ & $\begin{array}{c}5 \\
8.33 \%\end{array}$ & $\begin{array}{c}1 \\
1.67 \%\end{array}$ \\
\hline
\end{tabular}

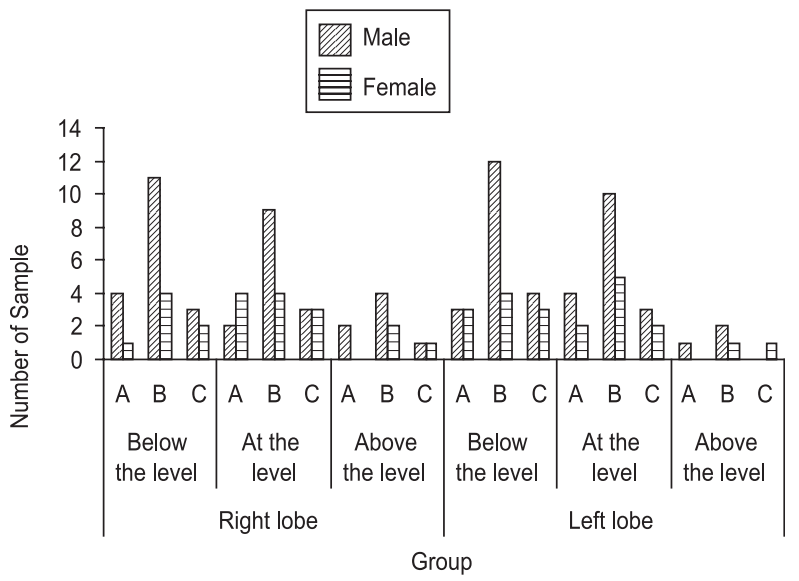

Fig.-1(a): Superior limit of the lobes of the thyroid gland in relation to the midpoint of the lamina of the thyroid cartilage.

\section{Discussion:}

Spencer and Waldman $(1965)^{7}$ performed scintillation scans of 50 thyroid gland (12 males and 38 females) and found that superior limit of the right lobe having a higher position than that of the left lobe in 41 cases, at the same level in 6 cases and lower in 3 cases. The inferior limit of the right lobe was found lower than that of the left in 23 cases, at the same level in 6 cases and higher position in 22 cases. Enayetullah $(1996)^{5}$ found that the superior limit of the lobes were below the midpoint of the lamina of the thyroid cartilage in most cases i.e. $66 \%$ of right and $54 \%$ of left lobes. On either side, $16 \%$ of cases were at the level of

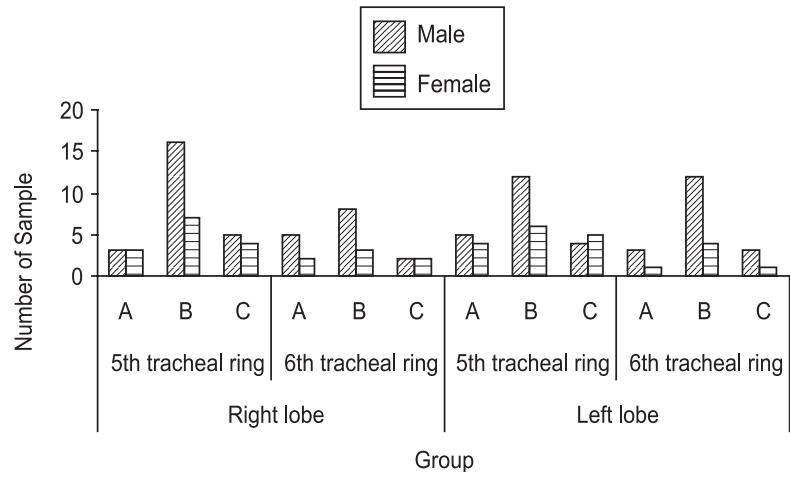

Fig. -1(b): Inferior limit of the lobes of the thyroid gland in relation to the tracheal ring.

the midpoint. Rest of the cases i.e. $30 \%$ of the left lobes and $18 \%$ of the right lobes extended above the midpoint. The lower limit of the lobes extended upto the $5^{\text {th }}$ tracheal ring in $78 \%$ of the cases on each side. Both of the lobes reached inferiorly upto the $6^{\text {th }}$ tracheal ring in $12 \%$ cases and the rest i.e. $10 \%$ upto the $4^{\text {th }}$ tracheal ring. Berkovitz (2005) ${ }^{1}$ stated that the lateral lobes of the thyroid gland found to extend up to the lamina of the thyroid cartilage along an oblique line and their bases are level with the $4^{\text {th }}$ or $5^{\text {th }}$ tracheal ring. Sultana $(2005)^{8}$ observed that among the left lobes, the superior limit was below the midpoint of the lamina of the thyroid cartilage in $83.3 \%$ of cases and 
$56.6 \%$ of the right lobes could reach the midpoint. $53.3 \%$ of the right lobes and $55 \%$ of the left lobes reached upto the $5^{\text {th }}$ tracheal ring inferiorly. Begum, Begum and Naushaba $(2006)^{9}$ found that among the right and left lobes, the superior limits were above the midpoint of the lamina of the thyroid cartilage in $35 \%$ and $31.67 \%$ cases, at the level of midpoint in $41.67 \%$ and $31.67 \%$, below the midpoint in $6.7 \%$ and $36.67 \%$ respectively. The inferior limits of the right and left lobes extended upto the $5^{\text {th }}$ tracheal ring in $38.33 \%$ and $43.33 \%$ and upto the $6^{\text {th }}$ in $61.67 \%$ and $56.67 \%$ cases respectively. Cicekcibasi et al. $(2007)^{10}$ examined 60 spontaneously aborted fetuses and found variations in the position of the upper and lower limits of the developing thyroid glands. The findings of the present study are more or less similar to the previous studies. The variability regarding the extension of the lobes of the thyroid gland is consistent with the failure to descent or excessive descent or with the relationship to anatomic structures having similar embryonic origin ${ }^{11}$.

\section{Conclusion:}

Further studies with larger sample and high technical backup, both in goiter endemic and non-endemic zones, are recommended.

\section{Acknowledgement:}

We would like to express our heartfelt thanks to the authority of Health, Nutrition \& Population Sector Programme (HNPSP), Directorate General of Health Services (DGHS) of the Government of the People's Republic of Bangladesh, and Dhaka Medical College, Dhaka for providing fund for this research work.

\section{References:}

1. Berkovitz BK. Neck and upper aero-digestive tract. In: Standring S, Ellis H, Heally JC, Johnson D, Williams A, Collins P, et al. eds. Gray's Anatomy:
The anatomical basis of clinical practice. $39^{\text {th }}$ ed. Edinburgh: Elsevier Churchill Livingstone; 2005. p. $560-4$.

2. Strachan MWJ, Walker BR. Endocrine disease. In: Boon NA, Colledge NR, Walker BR, Hunter JAA. eds. Davidson's principles and practice of medicine. $20^{\text {th }}$ ed. NewDelhi: Elsevier Churchill Livingstone; 2006. p. 744-62.

3. Anson BJ, McVay CB. eds. Surgical anatomy. $5^{\text {th }}$ ed. Philadelphia: W. B. Saunders; 1971. p. 265.

4. Grant CS. Surgical anatomy of the thyroid, parathyroid and adrenal glands. In: Fischer JE, Bland KI, Callery MP, Clagett GP, Jones DB, LoGerfo FW, et al. eds. Mastery of surgery. Vol.1. $5^{\text {th }}$ ed. Philadelphia: Lippincott Williams \& Wilkins; 2007. p. 388-97.

5. Enayetullah M. Gross and histomorphological study of the thyroid and parathyroid glands in Bangladeshi people [M.Phil.Thesis]. Dhaka: IPGMR, University of Dhaka; 1996. p. 15-17, 74.

6. Brown RA, Al-Moussa M, Beck JS. Histometry of normal thyroid in man. J Clin Pathol. 1986; 39: 475-82.

7. Spencer RP, Waldman R. Size and positional relationships between thyroid lobes in the adult as determined by scintillation scanning. J Nucl Med. 1965; 6: 53-8.

8. Sultana SZ. Gross and histomorphological study of postmortem thyroid gland in Bangladeshi people [M.Phil. Thesis]. Mymensingh: Mymensingh Medical College, University of Dhaka; 2005. p. 113.

9. Begum M, Begum J, Naushaba H. Morphological study of thyroid gland - a postmortem study. Bangladesh J Anat. 2006; 4(1): 23-27.

10. Cicekcibasi AE, Salbacak A, Seker M, Ziylan T, Tuncer I, Buyukmumcu M. Developmental variations and clinical importance of the fetal thyroid gland: a morphometric study. Saudi Med J. 2007 ; 28(4): 524-8.

11. Moore KL, Persaud TVN. The developing human: clinically oriented embryology. $6^{\text {th }}$ ed. Philadelphia: W. B. Saunders; 1998. p. 222-32. 